RULING THE SAVAGE PERIPHERY 



\title{
RULING THE SAVAGE PERIPHERY
}

\author{
Frontier Governance and the Making of \\ the Modern State
}

$\rightarrow$ BENJAMIN D. HOPKINS

\section{H}

Harvard University Press

Cambridge, Massachusetts

London, England

2020 
Copyright $\odot 2020$ by the President and Fellows of Harvard College

All rights reserved

Printed in the United States of America

First printing

Jacket design: Jill Breitbarth

Jacket art: Duncan I 890/DigitalVision Vectors/Getty Images

$$
\begin{gathered}
9780674246 \mathrm{I} 40 \text { (EPUB) } \\
9780674246 \mathrm{I} 57 \text { (MOBI) } \\
9780674246 \mathrm{I} 64 \text { (PDF) }
\end{gathered}
$$

The Library of Congress has cataloged the printed edition as follows:

Names: Hopkins, B. D., I978-

Title: Ruling the savage periphery : frontier governance and the making of the modern state / Benjamin D. Hopkins.

Description: Cambridge, Massachusetts : Harvard University Press, 2020. I Includes index.

Identifiers: LCCN 201904I799 | ISBN 9780674980709 (cloth) |

ISBN 9780674246140 (epub)

Subjects: LCSH: Borderlands-Political aspects. I Imperialism. I

Indigenous peoples-Government relations. I Frontier and pioneer life.

Classification: LCC JC 323 .H65 2020 I DDC $323 . \mathrm{II}$-dc23

LC record available at https://lccn.loc.gov/201904I799 
To Eliana, Tobias, and Olivia

You are the suns of my day, the moons of my night, the loves of my life.

-PAPI 
